\title{
Male Writers of Dānměi Literature: An Analysis of Fēitiānyèxiáng
}

\author{
Aiqing Wang \\ University of Liverpool, United Kingdom \\ orresponding author: Aiqing.Wang@liverpool.ac.uk \\ Submitted: 24-3-2021; Accepted: 21-4-2021 \\ DOI: $10.31291 / \mathrm{hn} . v 10 \mathrm{il} .607$
}

\begin{abstract}
In this paper, I investigate dānměi as a ground-breaking literary genre by means of scrutinising an illustrious male writer pseudonymed Fēitiānyèxiáng, and I propound that his works are exemplary as online writing. As a growing Chinese Internet literature, the female-oriented dānměi genre, aka Boys Love, has attracted legions of heterosexual fangirl producers and consumers as well as a meagre amount of their male counterparts. Among male dānměi writers, who are in an absolute minority, Fēitiānyèxiáng is celebrated for a wide range of innovative themes and magnificent storylines, and his fiction is replete with profound literary and historical allusions and elaborate and meticulous depictions. Furthermore, notwithstanding a non-reversible bipartite dichotomy between seme (top) and uke (bottom) roles, Fēitiānyèxiáng's writing is not featured by feminisation of uke, which is clichéd characterisation in not only the dānměi subculture, but also classical and modern Chinese literature. More significantly, Fēitiānyèxiáng's narratives are reality-oriented, addressing adverse circumstances in a real-world context and hence rendering characters more multi-faceted, and he does not circumvent realistic issues or create over-romanticised representation, analogous to his equivalent pseudonymed Nánkāngbáiqǔ.
\end{abstract}

Keywords: Dānměi; male writers; Fēitiānyèxiáng; non-feminised; realityoriented 


\begin{abstract}
Abstrak
Dalam artikel ini penulis meneliti dānměi sebagai genre sastra yang inovatif, dengan memelajari karya penulis pria terkenal bernama samaran Fēitiānyèxiáng. Penulis mengemukakan bahwa karya Fēitiānyèxiáng patut dicontoh sebagai tulisan online. Sebagai bentuk literature internet China yang sedang berkembang, genre dānměi yang berorientasi pada wanita, alias Boys Love, telah menarik banyak sekali produsen dan konsumen fangirl heteroseksual serta sejumlah kecil rekan pria mereka. Diantara penulis dānměi laki-laki yang merupakan minoritas mutlak, Fēitiānyèxiáng dirayakan karena berbagai tema inovatif dan alur ceritanya yang luar biasa. Fiksinya penuh dengan kiasan sastra dan sejarah yang mendalam serta penggambaran yang rumit dan cermat. Disamping itu, terlepas dari dikotomi bipartite yang tidak dapat dibolak-balik antara peran seme (atas) dan uke (bawah), tulisan Fēitiānyèxiáng tidak ditampilkan oleh feminisasi Uke yang merupakan karakterisasi klise tidak saja dalam subkultur dānměi, tetapi juga dalam sastra Tiongkok klasik dan modern. Lebih penting lagi, narasi Fēitiānyèxiáng berorientasi pada kenyataan, menangani keadaan buruk dengan konteks dunia nyata, oleh karenanya penggambaran karakter menjadi lebih beraneka ragam. Dia tidak mengelak dari masalah yang realistis, maupun menciptakan romantisme berlebihan dalam karyanya, sesuai dengan nama samaran Nánkāngbáiqǔ yang setara.
\end{abstract}

Kata kunci: Dānměi; male writers; Fēitiānyèxiáng; non-feminised; reality-oriented

\title{
Introduction
}

In the realm of Chinese Internet literature that emerged in China's cyberspace during the 1990s, there is a transgressive genre attaining renown and embracement, viz. 耽美 dānměi (Zheng 2014, Hockx 2015: 114), which literarily means 'indulgence in beauty' and concerns samesex romance and eroticism between 'beautiful' pubescent boys and youthful men (Yang and Xu 2016, 2017a, 2017b, Zhang 2016). Chinese dānměi literature was initially in a form of a Japanese cultural export 102 VOL. 10 NO. 1 JUNE 2021 
dubbed as shōnen'ai 'Boys Love', aka BL, which evolved from romanticised comics featuring 'beautiful young men' and targeting specifically at female audiences of the 1970s (McLelland 2000, Fujimoto 2015, McLelland and Welker 2015, Nagaike and Aoyama 2015). Since the 1990s, audio-visual and textual dānměi works have been proliferating from a marginalised niche market (Liu 2009, Yang and Bao 2012, Zhu and Zhang 2015) into an increasingly popular subculture with legions of fan producers/consumers (self-)referred to as 腐女 fünü 'rotten girls' (Chao 2016, 2017), coined after a Japanese terminology fujoshi (Galbraith 2015, Hester 2015, Nagaike 2015). Given its essence as female-oriented fantasies, the dānměi fandom is predominantly comprised of adolescent girls and adult women, who amount to $91 \%$ to $93 \%$ of the entire fanbase and are generally surmised to be heterosexual (Louie 2012, Xu and Yang 2014, Zhou and Li 2016, Zeng 2017) and underage (Zheng 2017, Wang 2018).

In the current dānměi subculture, fiction serves as the most-consumed subcategory (Wei 2014), rather than ACG (Anime, Comic and Games). A pioneering and leading online platform accommodating dānměi content is named 晋江文学城 Jinjiāng wénxué chéng 'Jinjiang Literature City' (henceforward Jìnjiāng), which has attained substantial commercial success since its launch in 2003 (Linder 2005, Feng 2009, 2013, Wang 2019): this well-organised, multi-functional website has hosted more than 3.89 million narratives with over 97.3 billion Chinese characters by January 2021 (Jìnjiāng 2021). The impressive achievement and quintessential status of Jìnjiāng are also manifested by an upsurge in its contracted writers and registered users: in 2012, the numbers were approximately 300,000 and 5 million respectively (Xu 
Male Writers of Dānměi Literature ...

and Yang 2013), whereas these figures have exceeded 1.68 million and 44.15 million respectively by January 2021 (Jìnjiāng 2021). As can be observed from data provided by Jinjiāng, users massively outnumber writers, which justifies the postulation that the overwhelming majority of Chinese 'rotten girls' are consumers, instead of producers, because the latter entails sufficient creation time and literary aptitude (Wang 2011, Xu 2015).

Albeit being a female-oriented subculture, dānměi has attracted a number of male fans, who are (self-)referred to 腐男 fǔnán 'rotten boys', following a Japanese terminology fudanshi (Welker 2006, Hester 2015, Nagaike and Aoyama 2015). Nonetheless, compared with their female counterparts, 'rotten boys' are substantially less active and visible in terms of online and offline interaction and nurturing a prosperous literary industry (Wang 2011, Wei 2014, Xu 2015). Furthermore, a considerable proportion of claimed fǔnán 'fans forge their identity online in order to seduce heterosexual girls intrigued by 'rotten' allusions ( $\mathrm{Xu}$ and Yang 2014). Analogous to male fans who only occupy a trivial minority of dānměi readership, the amount of male dannmei writers is also meagre, compared with their female counterparts (Zhao 2015).

It is notable that among all fictional works published on Jìnjiāng in February 2012, 73.13\% were non-fanfiction (Feng 2009, Xu and Yang 2013), which indicates that in the current dānméi market, original creation surpasses its fanfiction equivalent ( $\mathrm{Xu}$ and Yang 2014). Therefore, in this research I investigate original dānměi fiction published on Jìnjiāng exclusively. Moreover, despite the small quantity, dānměi narratives composed by male writers demonstrate high quality 
and deserve hermeneutic and interpretive scrutiny, so I explore nonfanfiction writing of male contracted Jìnjiāng writers.

In this paper, I explore the dānměi genre by means of analysing the works of an illustrious male dānměi writer pseudonymed 非天夜翔 Fēitiānyèxiáng (henceforward Fēitiān), who is affectionately nicknamed by fans as 肥田 féitián 'fertile/chubby land' as the homophone of 'Fēitiān' and 母鸡 mǔji ‘hen' due to his metaphor comparing authors to hens that produce eggs, ${ }^{1}$ as in Example (1). ${ }^{2}$

吃了一个好吃的鸡蛋, 请不要对母鸡产生太多兴趣; 喜 好, 母鸡表示由衷的幸福与感谢, 母鸡爱你。吃到一个雷人的臭蛋, 也请不要痛恨母鸡; 讨厌也罢, 母鸡只能说声哦, 对不起。

Chī le ȳ̄ gè hăo chī de jī dàn, qǔng bù yào duì mǔ jī chăn shēng tài dūō xìng qù; xǔ huān zuì hăo, mǔ jī biăo shì yóu zhōng de xìng fú yŭ găn xiè, mŭ jū ài nŭ. Chī dào yī gè léi rén de chòu dàn, yě qǔng bù yào tòng hèn mǔ jī; tăo yàn yě bà, mǔ jū zhĭ néng shuō shēng o, duì bù qŭ.

'When eating a tasty egg, please don't get too interested in the hen; it would be great if you liked it - the hen would love you and feel pleased and grateful. If the egg tastes awful, please don't hate the hen either; even if you dislike the egg, all the hen can do is to say "oh sorry".'

(Fēitiān. Trans. Mine)

I postulate that Fēitiān's fiction is characterised by preeminent artistic value, non-feminisation and reality-orientedness. The artistic value of Fēitiān's writing can be manifested by a wide range of innovative themes and ideologies, vivid imagination and imagery-evoking depiction, rich literary and historical allusions, as well as elaborateness and meticulousness. Furthermore, Fēitiān's works are reality-oriented, replete with virile characters. 
Male Writers of Dānměi Literature ...

\section{Method}

In this paper, I explore dānměi by means of scrutinising Fēitiān's fiction that has attained comprehensive embracement from readers and online literary platforms and thus massive attention from media. Fēitiān has been publishing on Jìnjiāng since the release of his 2008 narrative 天之 战记 Tiānzhīzhàn $J i$ 'An Account of a Heavenly War', and his latest novel 山有木兮 Shānyǒumù X̄̄ 'Trees in the Mountain' is still in progress. According to my calculation, Fēitiān, being a prolific writer, has thirty-three original narratives and six book reviews published on Jìnjiāng, which are constituted of 15,527,213 Chinese characters in total. One of Fēitiān's chefs-d'oeuvre, 图灵密码 Túlíng Mìmă 'Turing's Code', has received on average of 482,727 views per chapter and in total 241,843 comments by February 2021. Jìnjiāng, therefore, has been commending Fēitiān by means of bestowing successive awards upon him. For instance, eight of Fēitiān's novels have won Jìnjiāng's 'Outstanding Dānměi Work of the Year', and he has been listed as Jìnjiāng's 'Influential Writer of the Year' for four times. Driven by the popularity, the majority of Feitiān's narratives that were initially hosted by Jìnjiāng have been published in hard copy in both simplified and traditional Chinese language and become best-selling in domestic and overseas markets, exemplified by the 2012 online tale 与时光擦肩而过 Yǔ Shiguāng Cājiānérguò 'Passing by with Time' that has over a million hits (Economic Times 2016). Additionally, an array of novels such as 夺梦 Duó Mèng 'Dream Snatching' and 天地白驹 Tiāndì Báijū 'White Horse of the World' have been or will be adapted into audio-visual formats, including ACG, TV serials and radio plays (Sohu 2019). 
More significantly, readers' recognition contributes to that from the mainstream literary and academic fields, embodied by the fact that Fēitiān has been voted and nominated as a top 'Influential Writer' among over one thousand candidates for three times (Sina 2017, Liu 2019, China Daily 2020), and is hence acclaimed as the one of the five 'Exemplary Online Writers' by scholars on Chinese Internet literature (Shao 2019a). Fēitiān is exalted as "the well-established nanshen of female-oriented Internet writing' (女频网文界公认的“男神” nüpin wăngwénjiè gōngrènde 'nánshén') (Xiao 2019, Shao 2020) as well as ‘the only male dashen on female-oriented websites' (“女性向”网站中 唯一的男性大神 'nüxxìngxiàng' wăngzhànzhōng wéiyżde nánxìng dàshén), in which nánshén ('male divinity') and dashen ('big divinity') are readership-based neologisms metaphorically denoting top-ranked digital literature writers (Shao 2019b). Note that the amount of Chinese Internet writers is estimated to be 19.36 million in 2019 (Ni 2020), whereas those who can be classified as dàshén based on the size of their readership are less than 500 (Shao 2019b), which epitomises the iconic status of Fēitiān acknowledged by both readers and researchers.

Furthermore, readers have extended their affection for Fēitiān's writing to himself as a writer/person. Owing to moral scrutiny and government surveillance imposed upon dānměi, along with the dispersiveness of its virtual communities, there is void of official data concerning the exact size of dānměi fandom (Wei 2014, Zhang 2016), nor an accurate figure regarding Fēitiān's readership. Nevertheless, the enormousness of Fēitiān's fans can be embodied by his popularity on social media platforms. On Weibo, a micro-blogging platform with approximately 550 million monthly active users in March 2020 (Weibo 2020), Fēitiān's 
Male Writers of Dānměi Literature ...

account has attracted 1,659,835 followers by February 2021. There is also a dedicated Weibo 'super topic' virtual community established for Fēitiān, which has garnered intense attention: it has accumulated 401.82 million visits and 40,216 posts by February 2021. Therefore, it is justifiable to postulate that Fēitiān has a prodigious fanbase.

It is worth mentioning that apart from Fēitiān, there are at least three other pseudonyms arguably ascribed to this author. According to conjecture on cyberspace, apart from serving as a screenwriter for hit TV serials and a lyricist with various noms de plume, Feitiān has composed a famed dānměi novel 乱世为王 Luànshì Wéiwáng 'King of Turbulent Times' under a feminine pen name 顾雪柔 Gù Xuěróu (NetEase 2018, 2020). By virtue of its homosexual nature and connection with obscenity (Suzuki 1998, Nagaike 2003, McLelland 2005, 2016, 2017), in contemporary China, dānměi is subject to stringent official censorship and surveillance imposed by the party-state (Yi 2013, Ng 2015, Zhang 2017, Wang 2019). For the sake of selfprotection, Chinese dānměi producers write and publish pseudonymously (Xu and Yang 2013, Zeng 2017), rendering it arduous to pinpoint authors' real identities behind noms de plume. Through hermeneutically comparing and contrasting 'King of Turbulent Times' and fiction clearly ascribed to Feitiān, I propound that $\mathrm{Gu}$ Xuerou is indeed his another pen name, in that these 'two' authors are analogous in terms of characterisation, portraits of protagonists' demeanour and sexual intercourse, employment of an uncommon preposition cháo metaphors concerning stallions (see Example (5) below), etc. 


\section{Literature Review}

Chinese literature during both the classical and modern periods abounds with feminised masculinity of pubescent boys and youthful men assuming a penetrated role in male-male anal sexual intercourse. Analogously, feminisation of 受 shòu 'uke' (bottom; receptive) and even 攻 gōng 'seme' (top; insertive) characters is also commonly attested in dānměi content.

Late-imperial Chinese literature during late Ming (1368-1644) and early Qing (1644-1912) dynasties witnesses gender ambiguity and gender deviation, namely, a gradual disintegration of traditional division between the two sexes in social life, caused by '[f]lourishing commerce, a surplus of wealth, widespread education, a booming printing industry, rising individualism, prevailing hedonism, and the cult of qing' (Zhou 2003: 15). Ming-Qing romantic literature saliently concerns male homosexuality involving feminised male bodies (Tian 2015), which challenges Confucian precepts of filial piety and chastity (Volpp 2002). The three most prominent late Ming collections of male homoerotic pornography that have survived numerous waves of censorship (Vitiello 1992, 1996) are: 1) 弁而钗 Biànér Chāi 'Cap and Hairpins; Hairpins Beneath the Cap' as a syncretic negotiation of ideologies and crossed gender boundaries (McMahon 1988: 73-78，Vitiello 2000b，Wu 2017)；2) 龙阳逸史 Lóngyáng Yìsh ‘ 'The Forgotten Stories of Longyang' as a ferociously satirical portrait of male prostitution (Vitiello 2000a, 2000b, 2014); and 3) 宜春香质 Yíchūn Xiāngzhì 'Fragrant Essences of Spring' involving exquisite sexuality sported by the elite of equal status, 
Male Writers of Dānměi Literature ...

which signifies refinement (Ruan and Tsai 1987, Wu 1995, McMahon 2002). The construal of feminised males in homoerotic relationships can also be attested in Peking Opera in the Qing era, in which youthful epicene actors sing and perform in a dan role as female impersonators; these androgynous boys serve as social and/or erotic entertainers at literati banquets or permanent bondservants of 'connoisseurs' from the moneyed class (Mackerras 1972: 47, Wu 2003, 2004: 113-115, Stevenson and $\mathrm{Wu} 2013: 59)$.

In the iconic masterpiece 红楼梦 Hóng Lóu Mèng 'Dream of the Red Chamber/Mansion; The Story of the Stone' composed by the intellectual 曹雪芹 Cáo Xuěqín (1724-1764), there are also implicit and explicit portraits of male-male obscenities (Edwards 1990, Liu 2009, Wu 2017), and the receptive partners in homoerotic intimacy are depicted to be 'timid and bashful as a girl', 'shrinking and gentle' and 'as beautiful as flowers', and to possess feminine attributes such as 'winsome looks and gentleness of manner' (Chapter 9/28. Trans. Hawkes 1973). Similarly, in a realistic social novel 金瓶梅 Jìn Ping Méi 'The Plum in a Golden Vase' featuring heterosexual and homosexual promiscuity (Cheng and Lei 2014, Yao 2017), there are depictions of epicene boys who fall prey to the sexual exploitation of lecherous men occupying a higher social status (Lau and Ng 1989, Volpp 1996). Analogous descriptions of feminised youthful boys as receptive partners can also be attested in Ming-Qing compilations such as 情史 Qing Sȟ̌ 'History of Love/Qing' gleaned by 冯梦龙 Féng Mènglóng (1574-1646) and the 1632 collection 龙阳逸史 Lóngyáng Yishǐ 'The Forgotten Tales of Longyang', as well as those under the genre of 志怪 zhìguài 'accounts of miraculous paranormality and abnormality', exemplified by 仰斋志异 Liáozhāi 
Zhiỳ 'Strange Tales/Stories from a Chinese Studio; Strange Tales from the Liaozhai Studio' composed by 蒲松龄 Pú Sōnglíng (1640-1715) and 子不语 Ž̀ Bù Yǔ 'What the Master Would not Discuss' by 袁枚 Yuán Méi (1716-1798).

Modern Chinese literature, parallel to classical literature, is also replete with narratives depicting the enfeebled masculinity of young passive partners in male-male homosexual relationships. For instance, in an illuminating novella 兔 Tù 'Rabbit' composed by 舒庆春 Shū Qìngchūn (more renowned as 老舍 Lăo Shě) (1899-1966), the protagonist is a female impersonator of Peking Opera performance, who is surmised for homosexuality and male-male prostitution (Wang 1989, Kang 2009: 140), and this actor is characterised by epicene traits such as 白净 báijìng ‘fairness', 瘦弱 shòuruò ‘emaciation’ and 腼腆 miăntiăn 'bashfulness'. Feminised male images also appear in 白先勇 Pai Hsienyung’s pioneering LGBTQ work 藮子 Nièzǐ 'Crystal Boys' published in 1977 (Ji 2012, Jiang 2019) as well as 李碧华 Lǐ Bìhuá’s novel 霸王别 姬 Bàwáng Biéjì ‘Farewell My Concubine' (Zhou and Wu 2011, Li 2017). As for the realistic, thought-provoking online novel 北京故事 Bèijing Gùshì 'Beijing Story' which has been adapted into an awardwinning film 蓝宇 Lán $Y \breve{u}$, although it does not equip the protagonist assuming the passive role with excessively effeminate appearance (Example (4)), he is typically in a socially inferior position in relation to his penetrator partner; this top-bottom chasm accords with the traditional construal that anal penetration between males is intertwined with classism and ageism (Sommer 1997), so men are permitted to 
Male Writers of Dānměi Literature ...

sexually penetrate social inferiors of both genders to manifest their social superiority (Chou, 2001).

(2) 他长得不算白, 但脸上很干净, 面目十分清秀, 鼻子直 的, 嘴唇闭得很紧, 似乎没什么表情。

Tã zhăng de bù suàn bái, dàn liăn shàng hěn gān jìng, miàn mù shí fēn qìng xiù, bí zi zhí zhí de, zul̆ chún bì de hěn jǐn, sì hū méi shén me biăo qíng.

'He was not fair but had an even skin tone, delicate features and a straight nose; he pressed his tips tightly and remained expressionless.'

(Běijīng Gùshì. Trans. Mine)

\section{Result and Discussion}

In this paper, I argue that Fēitiān's writing is featured by artistic value, non-feminisation and reality-orientedness.

The artistic value of Fēitiān's fiction lies in four aspects: 1) a wide range of innovative themes and ideologies; 2) vivid imagination and imageryevoking depiction; 3) rich literary and historical allusions; and 4) elaborateness and meticulousness.

First, Fēitiān's narratives demonstrate myriads of distinct themes and storylines, ranging from Western fantasy, time travel, science fiction and online game at an early stage, to urban fantasy and Eastern fantasy at the current stage; moreover, his works are so innovative that they constantly inspire imitations and followers in the field of female-oriented writing (Shao 2019b). For instance, Fēitiān's 2015 novel 国家一级注册驱魔 师上岗培训通知 Guójiā Yūjí Zhùcè Qūmóshī Shànggăng Péixùn Tōngzhī 'Training Announcement of Level-One State Registered Exorcists' pioneers a niche 'exorcism' theme and introduces a new subcategory into the existing urban fantasies (Shao et al 2015); the ground-breaking 2014 novel 金牌助理 Jinpái Zhùlì 'Top-Ranking Assistant' initiates an era of composing fiction regarding the 112 | VOL. 10 NO. 1 JUNE 2021 
entrainment industry. Particularly, in a 2011 online novel entitled 二零 一三Erling Yīsān '2013’ that was renamed as 末日曙光 Mòrì Shǔguāng 'Dawn of the Doomsday' in print in 2013, Feitiān has created an astonishing apocalyptic world replete with zombies, which is regarded as a milestone in China's apocalyptic and post-apocalyptic fiction and has triggered a prevailing composition trend on Jinjiāng throughout the whole year of 2012 (Xiao 2019).

Moreover, Fēitiān's writing conveys magnificent ideologies such as heroism, patriotism and humanism, and illuminates his reflection on positive values (Xiao 2019). Taking the 2020 fantasy 定海浮生录 Dìnghăi Fúshēng Lì 'A Chronicle of Tranquil Ocean and Drifting Life' as an example: Fēitiān creates an atypical hero, who is not blessed with superpower or propitious luck, but falls prey to arduous and doomed fate and his own occasional vulnerability as an ordinary person; however, the protagonist eventually obtains success relying on his determination to safeguard the peace, which encapsulates Fèitiān's construal that one is supposed to assume responsibilities and hold adamantine mindset (Shao 2020).

Second, Fēitiān's artistic accomplishments can be encapsulated by a fecundity of imagination and richness of imagery-evoking representation. Impinged upon by Hollywood blockbusters and other popular media, Feitiān's writing, represented by the best-selling book '2013', outshines mediocre web-based pulp fiction by means of evoking film-like imagery of landscapes (Shao 2019b, Xiao 2019). His active, innovative imagination is also embodied by the wide range of themes and plot lines. 
Male Writers of Dānměi Literature ...

Third, the high quality of Fēitiān's fiction can be epitomised by profound historical and literary allusions, along with integration of fullyfledged genres of 演义 yănyì 'exposition/explication of meaning of events in history' (McLaren 2006, Ge 2007) and 武侠 wǔxiá 'martial chivalry; Chinese knighthood' (Liu 1967: 2, Teo 2009: 2, To 2019). In a 2017 novel 天宝伏妖录 Tiānbăo Fúyāo Lù 'A Chronicle of Subduing Demons in the Tianbao Period', Fēitiān combines the traditional yanyi and 东方奇幻/玄幻 dōngfāng qíhuàn/xuánhuàn 'Eastern fantasy' (Chao 2012: 114) with dānměi narration, thereby placing the female-oriented online romance to a broader picture (Xiao 2017, 2018). Fēitiān is highly competent in embedding dānměi romances in historical contexts: apart from 'A Chronicle of Tranquil Ocean and Drifting Life' and 'A Chronicle of Subduing Demons in the Tianbao Period' that have settings in the turbulent Eastern Jin (317-420) and the flourishing Tang (618-907) dynasties respectively, he has composed 我和妲己抢男人 Wó Hé Dájǐ Qiăng Nánrén 'Snatching the Man from Daji' that concerns the archaic Shang dynasty circa the $2^{\text {nd }}$ millennium BC and the semi-mythical Yellow Emperor and Jiang Ziya, as well as 战七国 Zhàn Qīguó 'Seven Warring States' that concerns the unified stage under the reign of Qin Shi Huang (259-210 BC). There are, of course, period narratives in which Fēitiān intentionally omits to specify historical periods, exemplified by 将军们的情书 Jiāngjūnmende Qíngshū 'Love Letters from Generals' and 放开那个受 Fàngkāi Nàgè Shòu 'Let Go of That Uke'. In these novels, Fēitiān depicts historic events, sites and personages in a serious manner, yet his humorous expressions render the texts entertaining simultaneously. 
Fēitiān's fiction is also characterised by rich literary allusions, illustrated by the title of his Jìnjiāng column, 海上生明月 Hăishàng Shēng Míngyuè, which is extracted from an exemplary Tang poem 望月怀远 Wàng Yuè Huái Yuăn composed by 张九龄 Zhāng Jiǔlíng (673-740), as in Example (3).

海上生明月, 天涯共此时。情人怨遥夜, 竟夕起相思。灭 烛怜光 满, 披衣觉露滋。不堪盈手赠, 还寝梦佳期

Hăi shàng shēng míng yuè, tiān yá gòng cǐ shí. Qíng rén yuàn yáo yè, jìng xī qŭ xiāng sī. Miè zhú lián guāng măn, pì yī jué lù zī. Bù kān yíng shǒu zèng, huán qĭn mèng jiā qū.

'Over the sea the moon shines bright; We gaze at it far, far apart. You might complain how long is night, And you would rise, lovesick at heart. I blow out candle, still there's light, I don my coat soon moist with dew. I can't hand you these moonbeams white But go to bed to dream of you.' (Gazing at the Moon and Longing for One Far Away. Trans. Xu 2004:

In addition to Tang poems, 词 cí-poetry flourishing during the Song (960-1279) dynasty (Wang 2007, Tao and Zhao 2010) is also cited in Fēitiān's fiction, such as 相见欢 Xiāngjiànhuān 'Ecstasy of Encounters', the title of which is a tune name. Similarly, in a historical story 国师帮帮忙 Guóshī Bāngbāngmáng 'Preceptor's Succour' set in the Tang dynasty, two volumes are entitled with tune names 扬州慢 Yángzhōumàn 'Slow Tune of Yangzhou' and 霜天晓角 Shuāngtiānxiăojiăo 'Horn at Frosty Dawn', and the other two volumes are entitled with 秦王破阵乐 Qínwáng Pòzhènlè 'Pozhen Music of the King of Qin' that is a large-scale musical performance popular in the Tang court (Li 2016, Bai 2018) and a piece of sheet music 沧海龙吟 Cānghăi Lóngyín 'Loong's Chanting in Ocean' of the Ming (1368-1644) 
Male Writers of Dānměi Literature ...

dynasty. In a 2010 work 武将观察日记 Wǔjiàng Guānchá Rìji ‘An Observation Diary of Martial Officials' that features renowned martial officials during the Three Kingdoms (220-280) period, I propose that Fēitiān adopts the format of long narratives known as 章回小说 zhānghuí xiăoshuō 'fiction in chapters' during the Qing (Hegel 1994), in that he uses chapter titles summarising pivotal information concisely with fixed syntactic structure (Yuan 2020) and classical expressions, e.g. 盛世承平帝位易主 Shèngshì Chéngpíng Dìwèi Yìzhǔ 'Succession to the Throne in the Peaceful Heyday’ (Chapter 70) and 万里河山英雄黄 土 Wànlǐ Héshān Yīngxióng Huángtǔ 'Heroes Buried in Enormous Land' (Chapter 71). Additionally, the title of the final chapter is disparate from previous ones involving identical number of Chinese characters, viz. 青 山依旧在·成败转头空 Qīngshān Yōjiù Zài Chéngbài Zhuăntóu Kōng, which I suggest is adapted from the introductory $c i$ in 三国演义 Sānguó Yănyì 'Romance of the Three Kingdoms' (Chun 2017), the pinnacle of zhanghui xiaoshuo and one of the four great masterpieces of Chinese literature (Hsia 1980: 35-36, Cook 2014), as in (4).

（4）滚滚长江东逝水, 浪花淘尽英雄。是非成败转头空。青 山依旧在, 几度夕阳红。白发渔樵江渚上, 惯看秋月春风。一壶浊 酒喜 相逢。古今多少事, 都付笑谈中。

Gǔn gǔn cháng jiāng dōng shì shuľ, làng huā táo jìn yīng xióng. Shì fēi chéng bài zhuăn tóu kōng. Qīng shān yī jiù zài, jù dù xī yáng hóng. Bái fà yú qiáo jiāng zhǔ shàng, guàn kàn qiū yuè chūn fêng. Yī hú zhuó jiǔ x̌̌ xiāng féng. Gǔ jīn duō shăo shì, dōu fù xiào tán zhōng.

'On and on the Great River rolls, racing east. Of proud and gallant heroes its white-tops leave no trace. As right and wrong, pride and fall turn all at once unreal. Yet ever the green hills stay To blaze in the west-waning day. Fishers and woodsmen comb the river isles. White-crowned, they've seen enough of spring and autumn tide To make good company over the wine jar, Where many a famed event Provides their merriment.'

(From Niànyīshǐ Táncí. Trans. Roberts 1999: 2) 
Fourth, Fēitiān's fiction is detail-enriched and precise. In addition to various types of spectacular scenery in fiction of different settings, Fēitiān explicitly and elaborately portrays a myriad of authentic and fictional objects, acts, events and venues in his fiction, e.g. a series of actions to starve, feed, train and befriend an untamed eagle (鹰奴 Yìng $N u ́$ 'Eagle Slave'; Chapter 26-27), a fierce battle and the fire, depredation, decease and exile it causes (江东双璧 Jiāngdōng Shuāngbì 'Jade to the East of the River'; Chapter 8), a splendid bordello in Xi' an of the High Tang era and a traditional snack called 樱桃䬬饠 yingtáo biluó ('A Chronicle of Subduing Demons in the Tianbao Period'; Chapter 27), the full execution procedure of a barbarous penalty in the imperial period called 凌迟 lingchí 'death by a thousand cuts' ('Ecstasy of Encounters'; Chapter 126), etc.

In terms of non-feminisation, it is embodied by the fact that characters in Fēitiān's fiction, especially semes, are marked by virility.

In dānměi literature, apart from androgynous demeanour highlighted by delicacy, emaciation and fair countenance, characters are also inclined to exhibit the so-called 撒娇 sājiāo conduct. Sājiāo, a complex umbrella notion integrating a wide range of deeds such as whining, pouting and flirting, can be interpreted as 'petulant; coquettish' (Farris 1988: 300), 'to show pettishness, as a spoiled child' (Farris 1994: 12-13), 'play cute' (Yueh 2013: 167), 'performed winsomeness/lovability' (Puzar and Hong 2018: 333), etc. As a feminine strategy of communication or a sexually suggestive posture (Chuang 2005, Sundararajan 2015: 125, Starr et al 2020), sājiāo-ness is the incarnation of societal infantilisation of pubescent girls and adult women so as to accommodate fetishes, so 
Male Writers of Dānměi Literature ...

this approach is deployed by females to manoeuvre and seduce (potential) partners, as well as to convince and demand peers and seniors of both genders (Farrer 2002: 85, Chuang 2005, Yueh 2013, 2017: 64). Dānměi fiction composed by female writers abounds with sājiāo-ness, as in novels featuring 娘(炮)受 niáng (pào) shòu 'sissy uke' and those involving sājiāo semes labelled as 少女攻 shàonü gōng 'maiden seme' or 萌攻 méng gōng 'cute seme’, e.g. 家有萌攻 Jiāyǒu Ménggōng 'Cute Seme at Home', 反派他过分美丽 Fănpài Tā Guòfèn Měilì 'The Antagonist is Excessively Beautiful' and 人渣反派自救系统 Rénzha Fănpài Zìiù Xitǒng 'The Evil Antagonist's Self-Rescue System'; the terminology sājiāo is even employed as a title of a novel pertaining to the show business by 狐狸不归 Húlíbùguī.

Nonetheless, divergent from the conventional stereotype of homosexual men in traditional literature and the clichéd representation in dānméi, Fēitiān's characterisation of male characters is featured by both physical and mental masculinity.

As for appearance, Fēitiān's seme characters are predominantly tall and athletic, featured by a dark complexion, bulging muscles and martial strength, as in Example (5). Similar portraits of protagonists and deuteragonists can be attested in narratives such as 灵魂深处 Línghún Shēnchù 'Deep in the Soul' (Chapter 1), 星辰骑士 Xīngchén Qíshi 'Star Knight' (Chapter 1), 幺儿 Yāoér 'The Youngest Son’ (Chapter 1), 朝圣 Cháoshèng 'Pilgrimage' (Chapter 2), 锦衣卫 Jinyīwèi 'Imperial Guards' (Chapter 6), etc. Even the uke characters, who are effeminate-looking and delicate-featured in an overwhelming majority of dānměi fiction, do not exhibit androgyny in Fēitiān's novels, as in Example (6). Although Fēitiān's aesthetics for masculine demeanour and personality attributes 118 VOL. 10 NO. 1 JUNE 2021 
accords with that of homosexual males in contemporary China (Zheng and Zheng 2015, 2016, Zheng et al 2016), it may not be able to accommodate 'rotten girls', because Chinese heterosexual women typically prefer feminised male faces, in stark contrast to homosexual men (Liu and Wu 2016, Zheng 2019). 二十八岁的英俊青年, 皮肤䵢黑, 身材瘦长, 腹肌有力, 胸 肌瘦削 结实, 身材好得像条骏马, 半长的头发湿淋淋地朝下滴水。 Er shí bā suì de yīng jùn qīng nián, pí fū yǒu hēi, shēn cái shòu cháng, fù jī yǒu lì, xiōng jī shòu xuē jiē shí, shēn cái hăo de xiàng tiáo jùn mă, bàn cháng de tóu fà shì lín lín dì cháo xià dī shuĭ.

'This twenty-eight-year-old tall man was dark-skinned and handsome. His athletic body was slim yet featured by a rippling six-pack and bulging pectoral muscles, rendering him as sexy as a stallion. His hair was still dripping with water and could do with a haircut.'

(Guójiā Yījí Zhùcè Qūmóshī Shànggăng Péixùn Tōngzhī. Chapter 1.

Trans. Mine)

(6) “看这模样, 也十七八了罢, 你要找怎么不找个漂亮点, 像女人 的。”但寻常人青睐的都是温柔旖㻈的少年, 游炎作男宠的话 也偏 大了, 看上去更没有女子柔弱之姿。

Kàn zhè mú yàng, yě shí qĩ bā le ba, nǐ yào zhăo zěn me bù zhăo gè piào liàng diăn, xiàng nǚ rén de. Dàn xún cháng rén qīng lài de dōu shì wēn róu y̌̌ nǐ de shào nián, yóu miăo zuò nán chǒng de huà yě piān dà le, kàn shàng qù gèng méi yǒu nü ž̆ róu ruò zhī zī.

“"He looks already seventeen or eighteen. Why don't you find a prettier and girlier one?" Men normally preferred soft and winsome boys, yet You Miao was too old to be a toy boy, and he wasn't feminine at all.'

(Luànshì Wéiwáng. Chapter 32. Trans. Mine)

As for personality, the semes and ukes created by Fēitiān are indomitable and audacious, not only in historical stories abounding with wars, slaughters and assassinations, but also in stories of modern and apocalyptic settings. In sharp contrast to entertaining characters created by his counterparts, such as those affectionately referred to as 四大骚攻 sì dà sāogōng 'top four coquettish semes' in the dānměi fandom, semes HERITAGE OF NUSANTARA: 
Male Writers of Dānměi Literature ...

in Fēitiān's fiction tend to be reliable yet sombre, exemplified by the silent seme who is nicknamed as 'mute' in 'Eagle Slave' (Chapter 2).

As can be seen from the non-feminisation of Fèitiān's narration, he does not ingratiate himself with dānměi readers, discrepant from a considerable proportion of online producers. In as early as 2013, the indispensability of 'rotten girl' readers was pointed out by a phenomenal male online writer 徐否 Xú Lěi (pseudonym: 南派三叔 Nánpàisānshū), who is celebrated for the award-winning tomb-raiding adventure series 盗墓笔记 Dàomù Bịji 'The Grave Robbers' Chronicles' (Liang 2014): according to $\mathrm{Xu}$, 一个腐女百万兵, 得腐女者得天下 yīgè fǔnü bǎiwàn bīng, dé fǔnü zhě dé tiānxià 'one rotten girl equals millions of solders; whoever wins their heart conquers the world' (Trans. Mine) (Xinhua News 2016, Wang 2020). Gigantic profit and fame have been bestowed upon 'The Grave Robbers' Chronicles' by its massive fanbase, so on Weibo the author exhibits a tolerant attitude towards 'rotten' fans' act of 'shipping', 3 even if the genre is not dānměi (Qiu 2015), which indicates author-audience interaction and its preponderant commercial ethos (Feng and Literat 2017).

What is noteworthy is that although Fēitiān does not intentionally ingratiate himself with 'rotten girls', he demonstrates appropriate respect for female readers: in narratives exemplified by 破罐子破摔 Pòguànzi Pòshuāi 'To Smash a Cracked Jar', female characters are not reduced to an inferior status as men's possessions, but described as intelligent participants and proactive creators of history $(\mathrm{Xu}$ and $\mathrm{Yang}$ 2014).

In terms of reality-orientedness, I posit that among Fēitiān's writing, there is list of reality-oriented, thought-provoking works, which 
enriches female-oriented literature with precious male experience (Shao 2019b). For instance, one of his representative novels is entitled 北城天 街 Běichéng Tiānjiēe 'Paradise Walk', which is extolled as an exception to cliché-ridden dānměi narration that is prone to excessively and surrealistically fantasise male-male romantic/erotic entanglements from a female perspective. On the contrary, this realistic, dolorous novel boldly unravels promiscuity, one-night stands, AIDS and decease, as well as the sense of bewilderment and loneliness and social and mental pressure of ordinary homosexual men in a modern metropolis (Zhao 2015). Moreover, as a Guangdong-born man living in Chongqiong (Economic Times 2016), Fēitiān chooses the setting in Chongqing and names the novel after a local retail complex, instead of deploying fictional cities and venues. Through portraying or simply alluding to stores and places in Chongqing, Fēitiān successfully creates a convivial atmosphere and evokes readers' memories and impulse to visit there, as indicated by related reviews and discussions on Douban (a popular Chinese review website for books, films and music) and Zhihu (a Chinese socialised Q\&A website parallel to Quora).

Furthermore, Fēitiān addresses issues beyond romance and does not circumvent difficulties characters may encounter in a real-world context, even if they are protagonists. That is to say, his realistic fiction bears no similitude with a subcategory of the so-called 爽文 shuăngwén 'feelgood writing' (Shao et al 2015, Shao 2019b, 2020), which is unflatteringly dubbed as 种马文 zhǒngmă wén 'stud fiction'. As pointed out Feng (2013: 10), male-authored Web-based 'stud fiction' blatantly presents male protagonists equipped with supreme artistry to reverse 
Male Writers of Dānměi Literature ...

history and vigorous sexual prowess to simultaneously attain numerous beautiful women (Feng 2013: 38); moreover, in time-travel 'stud' fantasies, an authorial 金手指 jīn shǒuzh ̌ 'golden finger' enables heroes to conquer the past via modern technologies (Feng 2013: 93). When consuming Fēitiān's fiction, however, readers are sometimes deprived of 'good feeling' owing to the lack of a 'golden finger'. To be more specific, albeit being protagonists, characters are plagued with adverse circumstances in the real world, rather than emotional entanglements in conventional romances, e.g. marginalisation and defamation ('Ecstasy of Encounters'; Chapter 46), impoverishment and low-paid employment ('Training Announcement of Level-One State Registered Exorcists'; Chapter 4), bipolar disorder and discrimination ('White Horse of the World'; Chapter 15), orphanhood and mockery ('A Chronicle of Subduing Demons in the Tianbao Period'; Chapter 5), etc.

More significantly, Fēitiān's fiction frequently fails to comply with the fandom expectation of 双洁 shuāng jié 'both purity', viz. an Internet neologism denoting the chasteness of both partners in hetero/homosexual relationships. I posit that the prevailing preference for shuangjie in the current dānměi fandom, along with its heterosexual romance equivalent, can be accounted for by the relatively sparse life/sexual experience of underage online readers. Among China's 940 million netizens, $49.7 \%$ of them have experience consuming digital literature, whereas approximately $56.5 \%$ of the entire netizen cohort are below the age of 30 (China Internet Network Information Centre 2020). As for the dānměi community, fans under 22 years old occupy $78.43 \%$ of the whole readership, with $82.35 \%$ of them start consuming dānměi content prior to the age of 18 (Zheng 2017). To accommodate underage 
fans, Jìnjiāng writers are expected to 排雷 pái léi 'clear mines', i.e. to post warnings, in the 文案 wénàn 'introductory pages', if the seme and/or uke protagonists have multiple sexual partners or even previous sexual experience. By contrast, in fiction with a contemporary setting, Fēitiān normally does not generate a surrealistic situation that attractive men are still void of sexual and/or love experience in their twenties or even thirties: for example, in 飘洋过海中国船 Piāoyángguòhăi Zhōngguó Chuán 'A Chinese Ship Sailing from Afar', the protagonist has a long-term ex-boyfriend, and in 'Top-Ranking Assistant', both protagonists have ex-girlfriends.

Moreover, Fēitiān's fiction sometimes entails a plot line regarding heterosexual marriage, which I propose is perceived as a typical 天雷 tiānléi 'thunderclap; ridiculously bad plot' (Feng 2013: 1) in dānměi fandom. For example, in 'Eagle Slave' with an imperial setting, both the seme and uke marry their empresses in two incarnations. More significantly, in a 2012 novel 王子病的春天 Wángzibingde Chüntiān 'Spring of Prince Syndrome' with a modern urban setting, the seme marries a woman he likes, encouraged by the uke (Chapter 52), which embodies Fēitiān's realistic style of writing. In the contemporary Chinese society, homosexuality tends to be construed as deviance from social norms (Kang 2012), and most Chinese people hold conservative attitudes towards homosexuality: according to statistics released by the Chinese General Social Surveys, approximately $78.53 \%$ of the respondents deem same-sex sexual encounters wrong (Xie and Peng 2018). Therefore, in contemporary China, notwithstanding flourishing LGBTQ rights movements (Micollier 2005, Schroeder 2015, Zheng 
Male Writers of Dānměi Literature ...

2015), including fast-growing advocacy of same-sex marriage (Jiang 2013), there are contract/cooperative marriages between gay men and lesbians so as to circumnavigate the intensive matrimonial pressure (Engebretsen 2014: 104-106) and to tacitly subvert the heteropatriarchal and heteronormative institution as an innovative intimate alliance (Kam 2010: 87-88) and silent resistance (Kam 2012: 99-103, Zhu 2018); additionally, there is even 'marriage fraud' that closeted homosexual men establish pretended heterosexual matrimonial relationships with unwitting, non-complicit women (Zhu 2018).

In this sense, Fēitiān's characterisation and depiction are analogous to another male Internet writer pseudonymed 南康白起 Nánkāngbáiqǔ, whose chef-d'oeuvre is 浮生六记 Fúshēng Liùji 'Six Accounts of Life'. In this semi-autobiography, Nankangbaiqi's same-sex partner is described as an average-looking man without elegant taste or behaviour (Example (7-9)), in sharp contrast to stereotypical dānměi which is 'indulgence in beauty', as can be seen from the terminology.

(7) 老公是头猪, 工作不到一年胖了二十几斤, 喝凉水都长肉。... 走路身上肉直㗜, 每天晚上一翻身床就咯吱咯吱响。Lăo gōng shì tóu zhū, gōng zuò bù dào ȳ̄ nián pàng le èr shí jǔ jīn, hē liáng shuǐ dōu

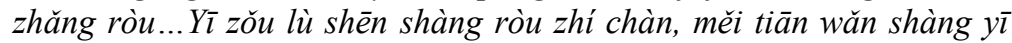
fān shèn chuáng jiù gè zhì gē zhī xiăng.

My hubby was a big - he put on over ten kilograms in less than a year after graduation. He would get fat just drinking water...His flesh shook while walking, and the bed creaked when he rolled over every night.'

(Fúshēng Liùjì. Chapter 1. Trans. Mine)

(8) 短碎发, 脸有点长, 有很多痘痘和坑坑洼洼, 霰弹枪打过似的。 小眼睛, 一边双一边单, 鼻子不高不低, 大嘴大下巴。只能说不丑, 老公这样评价自己。

Duăn sui fà, liăn yǒu diăn cháng, yǒu hěn duō dòu dòu hé kēng kēng wā wā, xiàn dàn qiāng dă guò shì de. Xiăo yăn jīng, yī biān shuāng yī biān dān, bí zi bù gāo bù dī, dà zul̆ dà xià bā. Zhĭ néng shuō bù chǒu, lăo gōng zhè yàng píng jià zì jĭ. 
'He had short hair and a long face full of zits and blemishes. One of his small eyes was monolid, yet the other one had a double eyelid; he had an ordinary nose and a big mouth and jaw. According to himself, he could barely be called "not ugly".

(Fúshēng Liùjì. Chapter 3. Trans. Mine)

(9) 我们也试过杂志上说的那种精致的生活, 谈谈诗词、聊聊法国 新浪潮的电影, 可惜老公不合作, 他宁可看足球。...插句题外话, 老 公常说“不臭怎么叫男人”, 于是抖动着自己的袜子说“闻一闻，疏筋 活络, 抖一抖, 精神抖擞”。理直气壮地对杂志皱皱鼻子说: 我就是 俗!

Wǒ men yě shì guò zá zhì shàng shuō de nà zhǒng jīng zhì de shēng huó, tán tán shī cí, liáo liáo fă guó xīn làng cháo de diàn y̌̌ng, kě xī lăo gōng bù hé zuò, tā nìng kě kàn zú qiú...Chā jù tí wài huà, lăo gōng cháng shuō bù chòu zěn me jiào nán rén, yú shì dǒu dòng zhe zì jĭ de wà zi shuō wén ȳ̄ wén, shū jīn huó luò, dǒu yī dǒu, jīng shén dǒu sǒu. Lǐ zhí qì zhuàng de duì zá zhì zhòu zhòu bí zi shuō: wǒ jiù shì sú!

'Influenced by posh magazines, I tried to be pretentious, rambling on poetry and French New Wave films, but my hubby wasn't cooperative and would rather watch football...Btw, my hubby kept preaching that "a man without stink is not a real man", so he often waved his sock in the air and said: "the smell of it makes you robust and puts you in high spirits". He justly wrinkled up his nose at posh magazines and declared: "I am vulgar!"”

(Fúshēng Liùjì. Chapter 1. Trans. Mine)

\section{Conclusion}

As one of the male producers who account for a trivial minority in the dānměi market, Fēitiān, 'the only male dashen on female-oriented websites', is famed for diverse themes and ideologies, active imagination and imagery-evoking portrayal. Furthermore, Fēitiān's writing is marked by historical settings and poetic allusions, as well as detail-enriched and elaborate depictions. More importantly, disparate from the stereotyped characterisation of classical and modern literature abounding with enfeebled masculinity of young passive partners in male-male same-sex dyads, male characters in Fēitiān's narratives are 
Male Writers of Dānměi Literature ...

featured by both physical and mental virility. Such masculinity, however, fails to comply with the prevailing preference for androgyny among dānměi fangirls. Fēitiān has also composed reality-oriented, thoughtprovoking works that are discrepant from online 'feel-good writing': instead of over-romanticising homosexual intimacy, his writing concerns realistic issues such as heterosexual marriage. Additionally, Fēitiān does not ingratiate himself with underage fans who expect surreal 'both purity', and creates imperfect yet multi-faceted characters. In this sense, Fēitiān bears similitude with his counterpart Nánkāngbáiqǔ whose chef-d’oeuvre is a realistic semi-autobiography depicting ordinary homosexual men in the real world.

\section{Endnotes}

1. Note that this metaphor was first employed by a renowned writer and scholar 钱钟书 Qian Zhongshu (1910-1998) upon the publication of his best-selling chef-d'oeuvre 围城 Weicheng 'Fortress Besieged', so as to discourage readers from showing interest beyond the book itself (Yang 1986).

2. In this paper, all quotations as well as titles and extracts of danmei fiction are translated by myself, unless specified otherwise.

3. The neologism 'shipping's is a slash terminology derived from the word 'relationship', which denotes fan practice of supporting particular real or imagined hetero-/homosexual relationships; fans are hence referred to as 'shippers' or CP 粉 CP fen 'coupling fans' in Chinese.

\section{References}

Bai, H. (2018). 《破阵乐》在唐代宫廷的兴衰及其音乐史价值 Pozhenyue zai tangdai gongtingde xingshuai jiqi yinyueshi jiazhi [Rise and decline of 'Po Zhen Yue' in Tang royal court and its value in music history]. Hundred Schools in Arts 01: 122-131.

126 | VOL. 10 NO. 1 JUNE 2021 
Chao, S.-c. (2012). Desire and Fantasy On-Line: A Sociological and Psychoanalytical Approach to the Prosumption of Chinese Internet Fiction. $\mathrm{PhD}$ thesis. University of Manchester.

Chao, S.-c. (2016). Grotesque Eroticism in the Dānměi Genre: The Case of Lucifer's Club in Chinese Cyberspace. Porn Studies 3.1: 6576.

Chao, S.-c. (2017). Cosplay, Cuteness, and Weiniang: The Queered Ke'ai of MaleCosplayers as 'Fake Girls'. In Boys' Love, Cosplay, and Androgynous Idols: Queer Fan Cultures in Mainland China, Hong Kong, and Taiwan, eds. Lavin Maud, Ling Yang and Jamie Jing Zhao, 20-44. Hong Kong: Hong Kong University Press.

Cheng, D. and Y. Lei. (2014). “欲望”与“至情”一《金瓶梅》与《红 楼梦》中的同性恋书写 Yuwang yu zhiqing-Jinpingmei yu Hongloumeng zhong de tongxinglian shuxie [Desire and loveHomosexual depictions in Jinpingmei and Honhloumeng]. Journal of Shaanxi University of Technology 04: 25-28.

China Daily. (2020). 第六届当当影响力作家评选揭晓 Diliujie dangdang yingxiangli zuojia pinguxan jiexiao [The $6^{\text {th }}$ Dangdang list of influential writers was released]. China Daily. 24 April 2020. https://caijing.chinadaily.com.cn/a/202004/24/ WS5ea26485a310c00b73c79559.html.

China Internet Network Information Centre. (2020). The $46^{\text {th }}$ China Statistical Report on Internet Development. Cyber Administration of China. September 2020.

Chou W.-S. (2001). Homosexuality and the Cultural Politics of Tongzhi in Chinese Societies. Journal of Homosexuality 40.3-4: 27-46.

Chuang, T.-i. (2005). The Power of Cuteness: Female Infantilization in Urban Taiwan. Greater China: 21-28.

Chun, X. (2017). 杨慎和《三国演义》卷首词 Yang Shen he Sanguo Yanyi juanshouci [Yang Shen and the introductory ci in Sanguo Yanyi]. Jinqiu 07.

Cook, J. W. (2014). Romance of the three kingdoms. In Encyclopedia of Renaissance literature ( $2^{\text {nd }}$ ed). Facts On File.

Economic Times. (2016). 人气作家非天夜翔出新书这位“大神”原来 住在重庆 Renqi zuojia Fēitiānyexiang chu xinshu, zhewei

HERITAGE OF NUSANTARA: 
Male Writers of Dānměi Literature ...

dashen yuanlai zhuzai Chongqing [The popular writer Feitiānyexiang is publishing a new book; this leading writer lives in Chongqing]. Economic Times. 09 October 2016. http://ient.ifeng.com/42697191/news.shtml?\&back.

Edwards, L. (1990). Gender Imperatives in Honglou meng: Baoyu's Bisexuality. Chinese Literature: Essays, Articles, Reviews 12: 6981.

Engebretsen, E. L. (2014). Convenient Resistance? Lala-Gay Contract Marriages. In Queer Women in Urban China: An Ethnography, 104-123. London: Routledge.

Farrer, J. (2002). Opening Up: Youth Sex Culture and Market Reform in Shanghai. Chicago: The University of Chicago Press.

Farris, C. (1988). Gender and Grammar in Chinese: With Implications for Language Universals. Modern China 14(3): 277-308.

Farris, C. (1994). A semiotic analysis of sajiao as a gender marked communication style in Chinese. In Unbound Taiwan: Closeups from a distance, eds. M. Johnson and F. Y. L. Chiu, 1-29. Chicago, IL: University of Chicago.

Feng, J. (2009). 'Addicted to Beauty': Consuming and Producing WebBased Chinese Dānměi Fiction at Jìnjiāng. Modern Chinese Literature and Culture 21.2: 1-41.

Feng, J. (2013). Romancing the internet: Producing and consuming Chinese web romance. Danvers, MA: Brill.

Feng, Y. and I. Literat. (2017). Redefining Relations Between Creators and Audiences in the Digital Age: The Social Production and Consumption of Chinese Internet Literature. International Journal of Communication 11: 2584-2604.

Fujimoto, Y. (2015). The evolution of bl as 'playing with gender': Viewing the genesis and development of BL from a contemporary perspective. In Boys Love Manga and Beyond: History, Culture, and Community in Japan, Eds. M. McLelland, K. Nagaike, K. Suganuma and J. Welker, 76-92. Jackson: University Press of Mississippi.

Galbraith, P. W. (2015). Moe talk: Affective communication among female fans of yaoi in Japan. In Boys Love Manga and Beyond: History, Culture, and Community in Japan, Eds. M. McLelland, K. Nagaike, K. Suganuma and J. Welker, 153-168. Jackson: University Press of Mississippi.

128 | VOL. 10 NO. 1 JUNE 2021 
Ge, L. (2007). Sanguo yanyi and the Mencian View of Political Sovereignty. Monumenta serica 55(1): 157-193.

Hawkes, D. (1973). Trans. The story of the stone. Vol I-V. Middlesex: Penguin Books.

Hegel, R. E. (1994). Traditional Chinese Fiction--The State of the Field. The Journal of Asian Studies 53. 2: 394-426.

Hester, J. T. (2015). Fujoshi emergent: Shifting popular representations of yaoi/BL fandom in Japan. In Boys Love Manga and Beyond: History, Culture, and Community in Japan, Eds. M. McLelland, K. Nagaike, K. Suganuma and J. Welker, 169-189. Jackson: University Press of Mississippi.

Hockx, M. (2015). Internet Literature in China. New York: Columbia University Press.

Hsia, C.-t. (1980). The Classic Chinese Novel: A Critical Introduction. Bloomington: Indiana University Press.

Ji, H. (2012). 中国现代文学史上第一部同性恋小说的沉浮一白先勇 小说 “《蕉子》热”原因探析 Zhongguo xiandai wenxueshishang diyibu tongxinglian xiaoshuode chenfu-Bai Xianyong xiaoshuo Niezi re fenzi [Ups and downs of the first gay novel in modern Chinese literature-A study on the zest of Crystal Boys written by Bai Xianyong]. Journal of Guangdong University of Education 32.2: 68-72.

Jiang, C. (2013). China's Gays and Lesbians Join the Global Debate on Same-Sex Marriage. Time. 01 May 2015. https://world.time.com/2013/05/01/chinas-gays-and-lesbiansstymied-by-lack-of-marriage-equality/.

Jiang, L. (2019). Transforming Emotional Regime: Pai Hsien-yung's Crystal Boys. eScholarship 3.1: 87-105.

Kam, L. Y. L. (2010). Opening Up Marriage: Married Lalas in Shanghai. In As Normal as Possible: Negotiating Sexuality and Gender in Mainland China and Hong Kong, ed. C. Yau, 87-102. Hong Kong: Hong Kong University Press.

Kam, L. Y. L. (2012). Shanghai Lalas: Female Tongzhi Communities and Politics in Urban China. Hong Kong: Hong Kong University Press. 
Kang, W. (2009). Obsession: Male Same-Sex Relations in China, 19001950. Hong Kong: Hong Kong University Press.

Kang, W. (2012). The decriminalization and depathologization of homosexuality in China. In China in and beyond the headlines, eds. T. B. Weston and L. M. Jensen, 231-249. Lanham, MD: Rowman and Littlefield.

Lau, M. P. and M. L. Ng. (1989). Homosexuality in Chinese culture. Culture, Medicine and Psychiatry 13: 465-488.

Li，D. (2016). 《秦王破阵乐》的诞生及其历史语境 Qinwang Pozhenyue de dansheng jiqi lishi yujing [Origin and historical context of Qinwang Pozhenyue]. Journal of Chinese Literature and History 03.

Li, X. (2017). 论魏晋南北朝美学的三个特征 Lun weijinnanbeichao meixuede sange tezheng [On three aesthetic features of Wei and Jin Dynasties and Southern and Northern Dynasties]. Journal of Zhengzhou University 50.6: 10-13.

Liang, P. (2014). 盗墓小说的魔力之源一剖析南派三叔的《盗墓笔 记》Daomu xiaoshuode moli zhiyuan-Poxi Nanpaisanshude Daomu Biji [Discovering the charm of tomb-raiding adventure fiction-On Nanpaisanshu's Daomu Biji]. Home Drama 340-341.

Linder, B. (2005). Web Literature. In Encyclopaedia of Contemporary Chinese Culture, eds. Edward L. Davis, 647. Oxon: Routledge.

Liu, B. (2019). 第五届当当影响力作家评选结果出晓: 220 位作家入 选 15 大榜单 Diwujie dangdang yingxiangli zuojia pingxuan jieguo chuxiao: 220 wie zujojia ruxuan 15 da bangdan [The fifth Dangdang influential writer list has been released: 220 writers were nominated for 15 major lists]. China Press and Publishing Media. 24 Aprial 2019. http://www.chinawriter.com.cn/n1/2019/ 0424/c403994-31048014.html.

Liu, J. J. Y. (1967). The Chinese Knight Errant. London: Routledge.

Liu, J. and Z. Wu. (2016). Xingbie ertaixing xiansuoxia daxueshengde miankong pianhao [Preferences for sexual dimorphic faces among university students]. The Guide of Science and Education 1: $166-167$.

Liu, L. (2009). 《左传》成书下限最晚在公元前 392 年考证 Zuozhuan chengshu xiaxian zuiwan zai gongyuanqian 392 kaozheng [Exploration on the composition date of Zuozhuan 
being 392 BC the latest]. Journal of Shenyang Normal University 33.3: 70-71.

Louie, K. (2012). Popular culture and masculinity ideals in East Asia, with special reference to China. The Journal of Asian Studies 71.4: 929-943.

Mackerras, C. P. (1972). The rise of the Peking opera, 1770-1870: social aspects of the theatre in Manchu China. Oxford: Clarendon Press.

McLaren. A. E. (2006). History repackaged in the age of print: the Sanguozhi and Sanguo yanyi. Bulletin of the School of Oriental and African Studies 69.2: 293-313.

McLelland, M. (2000). The Love Between 'Beautiful Boys' in Japanese Women's Comics. Journal of Gender Studies 9.1: 13-25.

McLelland, M. (2005). The World of Yaoi: The internet, censorship and the global 'boys' love' fandom. Australian Feminist Law Journal 23(1): 61-77.

McLelland, M. (2016). New Media, Censorship and Gender: Using Obscenity Law to Restrict Online Self-Expression in Japan and China. In Routledge Handbook of New Media in Asia, eds. L. Hjorth and O. Khoo, 118-129. Abingdon: Routledge.

McLelland, M. (2017). Introduction. In The End of Cool Japan: Ethical, Legal, and Cultural Challenges to Japanese Popular Culture, ed. M. McLelland, 1-30. London: Routledge.

McLelland, M. and J. Welker. (2015). An introduction to 'Boys Love' in Japan. In Boys Love Manga and Beyond: History, Culture, and Community in Japan, Eds. M. McLelland, K. Nagaike, K. Suganuma and J. Welker, 3-20. Jackson: University Press of Mississippi.

McMahon, K. (1988). Causality and Containment in SeventeenthCentury Chinese Fiction. Leiden: Brill.

McMahon, K. (2002). Sublime Love and the Ethics of Equality in a Homoerotic Novel of the Nineteenth Century: Precious Mirror of Boy Actresses. NAN NÜ 4.1: 70-109.

Micollier, E. (2005). Collective Mobilisation and Transnational Solidarity to Combat AIDS in China: Local Dynamics and 
Male Writers of Dānměi Literature ...

Visibility of Groups Defending Sexual and Social Minorities. Face to Face: Perspectives on Health 7: 30-38.

Nagaike, K. (2003). Perverse Sexualities, Perverse Desires: Representations of Female Fantasies and 'Yaoi Manga' as Pornography Directed at Women. U.S.-Japan Women's Journal 25: 76-103.

Nagaike, K. (2015). Do heterosexual men dream of homosexual Men?: BL fudanshi and discourse on male feminization. In Boys Love Manga and Beyond: History, Culture, and Community in Japan, Eds. M. McLelland, K. Nagaike, K. Suganuma and J. Welker, 199-209. Jackson: University Press of Mississippi.

Nagaike, K. and T. Aoyama. 2015. What is Japanese 'BL Studies?' A Historical and Analytical Overview. In Boys Love Manga and Beyond: History, Culture, and Community in Japan, eds. M. McLelland, K. Nagaike, K. Suganuma and J. Welker, 119-140. Jackson: University Press of Mississippi.

NetEase. (2018). 顾雪柔、非天夜翔、逐风天地、敛青锋是同一个 人? 是我孤陃寡闻了 $\mathrm{Gu}$ Xuerou, Fēitiānyexiang, Zhufengtiandi, Lianqingfeng shi tongyigeren? Shi wo gulouguawen le [Am I the only one who did know? Gu Xuerou, Fēitiānyexiang, Zhufengtiandi and Lianqingfeng are the same person]. NetEase. 30 November 2018. https://www.163.com/dy/article/E1T805UD 05391FRY.html.

NetEase. (2020). 他是网文界的“马甲之王”, 顾雪柔、逐风天地都是 他, 太多才多艺 Tashi wangwenjiede majia zhiwang, Gu Xuerou Zhufengtiandi doushi ta, tai duocaiduoyi [He's the 'King of pseudonyms'; both $\mathrm{Gu}$ Xuerou and Zhufengtiandi are him; he's so talented]. NetEase. 15 November 2020. http://mp.163.com/ article/FRGJ2L6M0545G5F9.html.

$\mathrm{Ng}$, L. (2015). China's elusive truths: Censorship, value and literature in the Internet age. In Censorship and the Limits of the Literary: A Global View, ed. N. Moore, 233-246. New York, London: Bloomsbury.

Ni, W. (2020). “网络文学+”大会开幕 国内网络文学作者已有近两千 万人 Wangluo wenxue + dahui kaimu guonei wangluo wenxue zuozhe yiyou jin liangqianwanren [Opening ceremony of the Internet literature+ conference; there are nearly 20 million online writers]. Beijing News. 04 September 2020. https://www.sohu. com/a/416462894_114988.

132 | VOL. 10 NO. 1 JUNE 2021 
Puzar, A. and Y. Hong. (2018). Korean Cuties: Understanding Performed Winsomeness (Aegyo) in South Korea. The Asia Pacific Journal of Anthropology 19.4: 333-349.

Qiu, X. (2015). 粉丝文化视野中的网络文学包装策略研究一以“南 派三叔”为例 Fensiwenhua shiyezhongde wangluo wenxue baozhuang celv yanjiu-Yi Nanpaisanshu weili [Promotion strategies of Internet literature in the fandom context-Using Nanpaisanshu as an example]. Young Writers: 77-81.

Roberts, M. (1999). Trans. Three Kingdoms: A Historical Novel. By G. Luo. Foreign Language Press/University of California Press: Beijing/Berkeley.

Ruan, F.-f. and Y.-m. Tsai. (1987). Male homosexuality in traditional Chinese literature. Journal of Homosexuality 14: 21-33.

Schroeder, W. F. (2015). Research, Activism, and Activist Research in Tongzhi China. In New Perspectives on Research, Activism and Media Cultures, eds. E. L. Engebretsen and W. F. Schroeder, 5780. Copenhagen: NIAS Press.

Shao, H. (2020). 幻想与现实的双重变奏—2019 年女频玄幻文学阅 读札记 Mengxiang yu xianshide shuangchong bianzou-2019 nian nvping xuanhuan wenxue yuedu zhaji [Dual depiction of fantasy and reality-Notes on 2019 female-oriented fantasy literature]. Wenyi Bao. 20 March 2020. http://www.scwlzjw. $\mathrm{com} /$ index.php? $\mathrm{m}=$ content $\& \mathrm{c}=$ index $\& \mathrm{a}=$ show $\&$ catid $=14 \& \mathrm{id}=83$ 5.

Shao, Y. (2019a). 网络文学 20 年典文.好文榜单发布 Wangluo wenxue ershinian dianwen haowen bangdan fabu [Release of the list of exemplary and outstanding works of Internet literature in the past twenty years]. Literature Paper. 01 January 2019. http://www.chinawriter.com.cn/n1/2019/0101/c40402730497850.html.

Shao, Y. (2019b). 网络文学的“断代史”与“传统网文”的经典化 Wangluo wenxuede duandaishi yu chuantong wangwende jingdianhua [The chronicle of Internet literature and the classification of traditional Internet literature]. Modern Chinese Literature Studies 02: 1-21. 
Shao, Y., Y. Ji and Y. Xiao. (2016). 2015 年网络文学: 顺势而为与内 力所趋 2015 nian wangluo wenxue: Shunshi erwei yu neili suoqu [Internet literature in 2015: External and internal driving forces of development]. China Writer. 19 February 2016. http://www. chinawriter.com.cn/zs/2016/2016-02-19/265689.html.

Sina. (2017). 当当书香节举办作家颁奖礼 向时代的写作者致敬 Dangdang shuxiangjie juban zuojia banjiangli, xiang shidaide xiezuozhe zhijing [Dangdang Book festival held a award ceremony to express respect for writers of this time]. Sina. 23 April 2017. http://book.sina.com.cn/news/tssd/2017-04-23/docifyepsch2711860.shtml.

Sohu. (2019). 7 月网剧备案发布! 《夺梦》将影视化 日剧《废柴》 疑翻拍 7 yue wangju beian fabu! Duomeng jiang yingshihua riju Feichai yi fanpai [Plan for July's online serials is released! Duomeng will be adapted; the Japanese play Feichai might be reshot]. Sohu. 06 September 2019. https://www.sohu.com/a/ 339175425_613523.

Sommer, M. (1997). The Penetrated Male in Late Imperial China: Judicial Constructions and Social Stigma. Modern China 23.2: 140-180.

Starr, R. L., T. Wang and C. Go. (2020). Sexuality vs. sensuality: The multimodal construction of affective stance in Chinese ASMR performances. Journal of Sociolinguistics 24: 492-513.

Stevenson, M. and C. Wu. (2013). Homoeroticism in Imperial China: A Sourcebook. New York: Routledge.

Sundararajan, L. (2015). Understanding Emotion in Chinese Culture: Thinking Through Psychology. New Yok: Springer.

Suzuki, K. (1998). Pornography or Therapy? Japanese Girls Creating the Yaoi Phenomenon. In Millennium Girls: Today's Girls around the World, Ed. S. Inness, 243-267. Lanham: Rowman and Littlefield.

Tao, W. and X. Zhao. (2010). On the Theatricality of the Ci-Poetry in Tang and Song Dynasties Frontiers of Literary Studies in China 4(4): 578-601.

Teo, S. (2009). Chinese Martial Arts Cinema: The Wuxia Tradition. Edinburgh: Edinburgh University Press. 
Tian, X. (2015). Slashing Three Kingdoms: A Case Study in Fan Production on the Chinese Web. Modern Chinese Literature and Culture 27.1: 224-277.

To, N. (2019). Disrupting the sword: The Wuxia legacy of Adam Cheng and the embodiment of Hong Kong cultural memory. Celebrity Studies 10.2: 268-275.

Vitiello, G. (1992). The Dragon's Whim: Ming and Qing Homoerotic Tales from 'The Cut Sleeve'. T'oung Pao 78. 4/5: 341-372.

Vitiello, G. (1996). The Fantastic Journey of an Ugly Boy: Homosexuality and Salvation in late Ming Pornography. Positions 4(2): 291-320.

Vitiello, G. (2000a). The Forgotten Tears of the Lord of Longyang: Late Ming Stories of Male Prostitution and Connoisseurship. In Linked Faiths: Essays on Chinese Religion and Traditional Culture in Honour of Kristofer Schipper, eds. P. Engelfriet and J. de Meijer, 227-247. Leiden: E. J. Brill.

Vitiello, G. (2000b). Exemplary Sodomites: Chivalry and Love in Late Ming Culture. NAN NÜ 2.2: 207-257.

Vitiello, G. (2014). China: Ancient to Modern. In The Cambridge History of Gay and Lesbian Literature, eds. E. L. McCallum and M. Tuhkanen, 125-142. Cambridge: Cambridge University Press.

Volpp, S. (1996). Gender, power, and spectacle in late imperial Chinese theater. In Gender Reversals and Gender Cultures: Anthropological and Historical Perspectives, ed. S. P. Ramet, 138-147. London and New York: Taylor \& Francis Group.

Volpp, S. (2002). The Literary Circulation of Actors in SeventeenthCentury China. The Journal of Asian Studies 61.3: 949-984.

Wang, B. (2020). “男色经济”变现之路 Nanse jingji bianxian zhilu [The way to monetise males as products]. Biz Leaders. 14 December 2020. https://www.biz-leader.com/newsinfo/983348. html.

Wang, C. Y. (2019). Officially Sanctioned Adaptation and Affective Fan Resistance: The Transmedia Convergence of the Online Drama Guardian in China. International Journal of TV Serial Narratives: 45-58. 
Wang, D. D.-w. (1989). Lao She's Wartime Fiction. Modern Chinese Literature 5.2: 197-218.

Wang, S. (2018). “腐文化”社群中的女性身份认同与空间建构 Fuwenhua shequnzhongde nvxing shenfen rentong yu kongjian jiangou [Identity recognition and space construction of women in rotten culture communities]. Journal of News Research 11: 57-58.

Wang, T.-T. (2011). Tanbi novels and fujoshi: A new romance for young Chinese women. In Arts: A science matter, eds. M. Burguete and L. Lam, 317-332. Singapore: World Scientific Publishing.

Wang, Z. (2007). Evolution of Ci Poetry of the dynasties of Tang and Song in the perspective of dissociation and integration of Shi and Ci. Frontiers of Literary Studies in China 1(3): 449-475.

Wei, J. (2014). Queer Encounters between Iron Man and Chinese Boys' Love Fandom. Transformative Works and Cultures 17. https://doi.org/10.3983/twc.2014.0561.

Weibo. (2020). Weibo Reports First Quarter 2020 Unaudited Financial Results. http://ir.weibo.com/news-releases/news-release-details/ weibo-reports-first-quarter-2020-unaudited-financial-results.

Welker, J. (2006). Beautiful, borrowed, and bent: 'Boys' Love' as girls' love in Shojo manga. Signs 31 (3): 841-870.

Wu, C. (1995). Bian er chai, Yichun xiangzhi de niandai kaozheng jiqi shehui wenhua yiyifawei [The dating and socio-cultural significance of Bian er chai and Yichun Xiangzhi]. Journal of Oriental Studies 32.2: 67-73.

Wu, C. (2003). 'Beautiful boys made up as beautiful girls': antimasculine taste in Qing China. In Asian Masculinities: The Meaning and Practice of Manhood in China and Japan, eds. K. Louie and M. Low, 19-40. London: RoutledgeCurzon.

$\mathrm{Wu}$, C. (2004). Homoerotic Sensibilities in Late Imperial China. London: RoutledgeCurzon.

Wu, I-H. (2017). Lust as Prerequisite: Eroticism in The Story of the Stone. Journal of Chinese Literature and Culture 4.1: 129-159.

Xiao, Y. (2017). 商业化与原创力的多种可能性 Shangyehua yu yuanchuangzide duozhong kenengxing [Various possibilities of commercialisation and originality]. Literature Paper. 10 October 
2017. http://www.chinawriter.com.cn/n1/2017/1010/c40402729578921.html.

Xiao, Y. (2018). 历史演义”与“东方奇幻”的女频引渡一评非天夜翔 《天宝伏妖录》Lishi yanyi yu dongfang qihuan de nvpin yindu - Ping Fēitiānyexiang Tianbaofuyaolu [Historical romance and Eastern fantasy on the female-oriented platform-Analysing Fèitiānyexiang's Tianbaofuyaolu]. Chinese Journal of Literary Criticism 01: 126-127.

Xiao, Y. (2019). 颠覆“倾城之恋”,重写末世文明一评非天夜翔《二 零一三》Dianfu qingchengzhilian, chongxie moshiwenmingPing Fèitiānyexiang Erlingyisan [Deviating the earthshaking love and rewriting the apocalyptic civilisation-Analysing Fēitiānyexiang's 2013]. Contemporary Chinese Literature Studies 02: 133-134.

Xie, Y. and M. Peng. (2018). Attitudes Toward Homosexuality in China: Exploring the Effects of Religion, Modernizing Factors, and Traditional Culture. Journal of Homosexuality 65.13: 1758-1787.

Xinhua News. (2016). 疯狂消费男色 没完没了卖腐 真的好吗? Fengkuang xiaofei nanse meiwanmeiliao maifu zhende haoma? [Is it suitable to consume male beauty and use homosexuality as a selling point?]. Xinhua News. 24 May 2016. http://www.xinhuanet.com/ent/2016-05/24/c_1118918498.htm.

Xu, Y. (2015). 网络女性写作的生产与生态 Wangluo nvxing xiezuode shengchan yu shengtai [The production and context of feminine writings on the Internet]. Journal of Peking University 52.1: 153160.

$\mathrm{Xu}$, Y. and L. Yang. (2013). Forbidden love: incest, generational conflict, and the erotics of power in Chinese BL fiction. Journal of Graphic Novels and Comics 4:1: 30-43.

Xu, Y. and L. Yang. (2014). 腐女“腐”男:跨国文化流动中的耽美、腐 文化与男性气质的再造 Funv Funan: Kuaguo wenhua liudongzhongde dānměi, fuwenhua yu nanxingqizhide zaizao [Rotten girls and rotten boy: Dānměi, rotten culture and representation of masculinity in transcultural communication]. Cultural Studies 03: 3-25. 
Xu, Y. (2004). Trans. 中国古诗精品三百首 Zhongguo gushi jingpin sanbanshou. 300 gems of classical Chinese poetry. Beijing: Peking University Press.

Yang, J. (1986). Preface. In 记钱钟书与《围城》Ji Qian Zhongshu xie Weicheng [Qian Zhongshu and Weicheng]. Changsha: Hunan People's Publishing House.

Yang, L. and H. Bao. (2012). Queerly intimate: Friends, fans and affective communication in a Super Girl fan fiction community. Cultural Studies 26.6: 842-871.

Yang, L. and Y. Xu. (2016). Dānměi, Xianqing, and the making of a queer online public sphere in China. Communication and the Public 1.2: 251-256.

Yang, L. and Y. Xu. (2017a). 'The love that dare not speak its name': The fate of Chinese dānmèi communities in the 2014 anti-porn campaign. In The End of Cool Japan: Ethical, Legal, and Cultural Challenges to Japanese Popular Culture, ed. M. McLelland, 163183. London: Routledge.

Yang, L. and Y. Xu. (2017b). Chinese Dānměi Fandom and Cultural Globalization from Below. In Boys' Love, Cosplay, and Androgynous Idols: Queer Fan Cultures in Mainland China, Hong Kong, and Taiwan, eds. L. Maud, L. Yang and J. J. Zhao, 3-19. Hong Kong: Hong Kong University Press.

Yao, J. (2017). 同性恋书写视阈下《金瓶梅》与《红楼梦》之互文 性解 读 Tongxinglian shuxie shiyuxia Jinpingmei yu Hongloumeng zhi huwenxing jiedu [The intertexualised interpretation of homosexual depiction between The golden lotus and A story of the stone]. Journal of Southwest University of Science and Technology 01: 46-51.

Yi, E. J. (2013). Reflection on Chinese boys' love fans: An insider's view. Transformative Works and Culture 12. DOI: https://doi.org/10.3983/twc.2013.0424.

Yoshimoto, T. (2008). Fudanshi ni kiku [Interviewing fudanshi]. Japan: Self-published.

Yoshimoto, T. (2010). Fudanshi ni kiku 2 [Interviewing fudanshi 2]. Japan: Self-published.

Yuan, R. (2020). 明清章回小说回目特点和翻译技巧 Mingqing zhanghui xiaoshui huimu tedian he fanyi jiqiao [The 
characteristics and translation skills of chapter titles of Ming \& Qing dynasty novels]. Cultural and Artistic Innovation 3.2: 1821.

Yueh, H.-I. S. (2013). Body Performance in Gendered Language Deconstructing the Mandarin Term Sajiao in the Cultural Context of Taiwan. Ricerche di Pedagogia e Didattica-Journal of Theories and Research in Education 8.1: 159-182.

Zeng, W. (2017). 浅析耽美文化传播过程一以网络传播和腐女角度 分析 Qianxi dānměi wenhua chuanbo guocheng-Yi wangluo chuanbo he funv jiaodu fenxi [Analysis of the spread process of dānměi culture-From the aspects of Internet communication and rotten girls]. Chuanbo yu Banquan 44.1: 136-137.

Zhao, L. (2015). 从《北城天街》看中国男同性恋者的生存现状 Cong Beicheng tianjie kan zhongguo nantongxinglianzhe de shengcunzhuangkuang [On the status quo of male homosexuals in China from Beicheng tianjie]. Journal of Mudanjiang University 10: 61-63.

Zhang, C. Y. (2017). When Feminist Falls in Love with Queer: Dan Mei Culture as a Transnational Apparatus of Love. Feminist Formations 29.2: 121-146.

Zhang, C. (2016). Loving Boys Twice as Much: Chinese Women's Paradoxical Fandom of 'Boys' Love' Fiction. Women's Studies in Communication 39(3): 249-267.

Zheng, L. (2017). 耽美文化在青少年女性群体中的传播与影响研究 Dānměi wenhua zai qingshaonian nvxing qunti zhongde chuanbo yu yingxiang yanjiu [The spreading and influence of tanbi culture in adolescent females]. Journal of Shandong Youth University of Political Science 02: 29-33.

Zheng, L. (2019). Preference for Male Facial Masculinity as a Function of Mental Rotation Ability in Gay and Bisexual Men, but Not in Heterosexual Men and Women in China. Frontiers in Psychology 10: 2419 .

Zheng, L., J. Zhang and Y. Zheng. (2016). Relationships between pathogen disgust sensitivity and preference for male facial masculinity in gay men in China. Personality and Individual Differences 92: 33-36. 
Zheng, L. and Y. Zheng. (2015). Young gay men's sexism predict their male facial masculinity preference in China. Personality and Individual Differences 76: 183-186.

Zheng, L. and Y. Zheng. (2016). Preferences for Masculinity Across Faces, Bodies, and Personality Traits in Homosexual and Bisexual Chinese Men: Relationship to Sexual Self-Labels and Attitudes Toward Masculinity. Archives of Sexual Behavior 45: 725-733.

Zheng, T. (2015). Tongzhi Living: Men Attracted to Men in Postsocialist China. Minneapolis and London: University of Minnesota Press.

Zhou, S. and D. Wu. (2011). Bawang Bieji xiaoshuo wenben he dianying wenben de xushixue bijiao [A narrative comparison between the novel text and movie text of Farewell my concubine]. Journal of Minjiang University 32.2: 48-54.

Zhou, Y. and Q. Li. (2016). “腐女”群体与耽美亚文化的新媒体传播 Funv qunti yu dānměi yanwenhua de xinmeiti chuanbo [New media communication of rotten girl groups and dānměi subculture]. Media Observation 06: 31-33.

Zhou, Z. (2003). Androgyny in Late Ming and Early Qing Literature. Honolulu: University of Hawai'i Press.

Zhu, J. (2018). 'Unqueer' kinship? Critical reflections on 'marriage fraud' in mainland China. Sexualities 21(7): 1075-1091.

Zhu, Y. and M. Zhang. (2015). 身份认同视野下耽美迷群的网媒使用 Shenfen rentong shiyexia dānměi miqunde wangmei shiyong [The use of Internet media of dānměi fandom under the view of identity recognition]. News World 11: 133-134.

Zsila, Á., D. Pagliassotti, R. Urbán, G. Orosz, O. Király and Z. Demetrovics. (2018). Loving the love of boys: Motives for consuming yaoi media. PLoS One 13(6): e0198895. DOI: 10.1371/journal.pone.0198895. 